\title{
Grain dust originating from organic and conventional farming as a potential source of biological agents causing respiratory diseases in farmers
}

\author{
Wioletta A. Żukiewicz-Sobczak ${ }^{1}$, Grażyna Cholewa ${ }^{1}$, Ewelina Krasowska ${ }^{1}$, Jolanta Chmielewska-Badora ${ }^{1}$, \\ Jacek Zwoliński², Paweł Sobczak ${ }^{2}$
}

'Department of Allergology and Environmental Hazards, Institute of Rural Health, Lublin, Poland

Head of Department: Wioletta A. Żukiewicz-Sobczak PhD

2Department of Food Engineering and Machines, University of Life Sciences, Lublin, Poland

Head of Department: Prof. Kazimierz Zawiślak

Postep Derm Alergol 2013; XXX, 6: 358-364

DOI: 10.5114/pdia.2013.39434

\begin{abstract}
Introduction: Agricultural producers are exposed to a number of different health risks associated with their work environment.

Aim: The objective of the study was to assess the degree of colonization by fungi in terms of quantity and in terms of variety of species the samples taken from the settled dust from combine threshing of rye cultivation from organic and conventional farms in the Province of Lublin.

Material and methods: This paper is a preliminary quantitative assessment of the species of fungi colonizing the samples of settled dust collected during combine threshing from organic and conventional farms in the Province of Lublin. One of the stages of the project was the classification of biosafety BSL (biosafety level) of selected isolates and API ZYM tests to evaluate the potential ability of isolates to cause adverse health effects. To determine the concentration and composition of fungi in collected samples plate dilution method was used with two media: Malt Agar and Potato Dextrose Agar.

Results: Most commonly isolated fungi in settled dust samples collected during combine threshing from organic farms, on PDA medium were: Alternaria alternata and Aureobasidium pullulans. Cultures on MA medium were dominated by Alternaria alternata, Mycelia sterilia and Fusarium poae. In samples of dust from conventional crops, the predominant species was Alternaria alternata on PDA medium and on MA medium.

Conclusions: The obtained results show a potential risk of people involved in agricultural work.
\end{abstract}

Key words: organic agriculture, conventional crops, molds, alveolitis allergica.

\section{Introduction}

Conventional farming uses measures of industrial production, including fertilizers and chemical pesticides and industrial feed, ensuring higher productivity of plants and animals, and higher efficiency than organic farming [1]. Organic farming is a farming system based on respect for the principles of crop rotation, covering the soil with plants throughout the growing season, using mainly natural and organic fertilizers, while limiting mineral fertilizers and plant protection products, take action to protect plants, compliance with standards of space and cleanliness of the premises including the definition of livestock stocking limit on the area of agricultural land [2].
Agricultural producers are exposed to a number of different health risks associated with the work they undertake. One such factor is the dust of biological origin (organic powder). Depending on the place of origin it may contain various components of cereals, other plants, molds and fungi, mycotoxins, bacteria, dust mites, insect fragments and animal excretions of very diverse composition [3, 4].

\section{Aim}

The objective of the study was to assess the degree of colonization by fungi in terms of quantity and in terms of variety of species the samples taken from the settled

Address for correspondence: Wioletta A. Żukiewicz-Sobczak PhD, Department of Allergology and Environmental Hazards, Institute of Rural Health, 2 Jaczewskiego St, 20-090 Lublin, Poland, phone: +48 698143 743, e-mail: wiola.zukiewiczsobczak@gmail.com Received: 13.08.2013, accepted: 18.09.2013. 
dust from combine threshing of rye cultivation from organic and conventional farms in the Province of Lublin.

Selected genera and species of fungi were ranked in terms of health risk to people doing different types of work in agriculture - the class of Biosafety Levels (BSL). The selected isolates were also evaluated for the presence and activity of extracellular hydrolytic enzymes (API ZYM test, bioMérieux), which may indicate the potential ability of isolates to cause adverse health effects. This type of study has been designed because of the dynamic growth in the number of organic farms in Poland, a large exposure to agricultural producers to organic dusts and potential ability of fungi and their metabolites of inhaled organic dust to cause respiratory diseases.

\section{Material and methods}

The material consisted of settled dust samples collected during combine threshing in two agricultural systems: organic and conventional in the Province of Lublin (10 settled dust samples from each system of cultivation a total of 20 samples in the months of July-August 2012).

To determine the concentration and composition of fungi in samples two media were used: Malt Agar (Malt Agar, Becton, Dickinson and Company) and Potato Dextrose Agar (PDA, Becton, Dickinson and Company) and the method of plate dilution with the addition of Tween 80. The study was conducted in two parallel repetitions. Malt Agar cultures were incubated at $30^{\circ} \mathrm{C}$ for $72 \mathrm{~h}$ and at room temperature for another $72 \mathrm{~h}$ and PDA cultures were incubated at $24^{\circ} \mathrm{C}$ for $144 \mathrm{~h}$. Species composition of fungal flora was determined using macroscopic and microscopic methods and keys and atlases [5-10] and quantities were expressed in units of CFU/g.

Isolated fungi were ranked for the relevant class of biosafety BSL. In some species of fungi isolated from samples the hydrolytic enzymes activity was determined using the API ZYM test (bioMérieux). Selected strains were grown in PDA for 16 days at $24^{\circ} \mathrm{C}$. Then the collected fragments of fungal culture with a diameter of 5-6 mm were placed in two liquid media: Sabouraud Dextrose Broth (Becton, Dickinson and Company) and Czapek-Dox Broth (Becton, Dickinson and Company). The cultures and controls were incubated for 16 days at $24^{\circ} \mathrm{C}$. Culture supernatants after centrifugation were used in the API ZYM test. The next steps were complied with the API ZYM test manufacturer's instructions.

\section{Results}

\section{Identification of fungi}

In the analyzed samples of the rye dust from organic farms most often the following fungi species were found: Alternaria alternata, Aureobasidium pullulans, Mycelia sterilia, Fusarium poae, Cladosporium macrocarpum. The dust of rye from conventional farms was dominated by
Alternaria alternata, Cladosporium macrocarpum, Fusarium poae, Fusarium tricinctum and Mycelia sterilia. The most diverse in terms of species composition were dust samples from conventional crops isolated on MA, and the least diverse sample came from the dust samples from organic farms isolated on PDA medium, but the differences were small in number.

Most commonly isolated fungi in settled dust samples collected during combine threshing from organic farms, on PDA medium were: Alternaria alternata (16.1\%) and Aureobasidium pullulans (15.3\%). Cultures on MA medium were dominated by Alternaria alternata (24.5\%), Mycelia sterilia (11.9\%) and Fusarium poae (10\%). In samples of dust from conventional crops, the predominant species was Alternaria alternata on PDA medium in $12.6 \%$, and on MA medium - 18.2\% (Table 1).

The most diverse isolates from the dust of both conventional and organic farming were cultured on PDA medium. The concentration of fungi in samples collected from dust settled during combine threshing derived from organic farms isolated on PDA were in the range from $965 \times 10^{3}$ to $7170 \times 10^{3} \mathrm{CFU} / \mathrm{g}$, and isolated on MA ranged from $635 \times 10^{3}$ to $6060 \times 10^{3} \mathrm{CFU} / \mathrm{g}$. The concentration of fungi in samples collected from settled dust during combine threshing from conventional farms isolated on PDA were in the range from $1300 \times 10^{3}$ to $13445 \times 10^{3}$ CFU/g, and on MA medium ranged from $1105 \times 10^{3}$ to $5305 \times 10^{3}$ CFU/g. In general, higher levels of fungi were found in settled dust samples collected during combine threshing from conventional farms compared to organic farms isolated on PDA medium. In organic farming, conventional antifungal preparations and plant protection products are not applied, however relevant strains for this type of cereals cultivation better deal with threats such as mold fungi [11]. When the substrate is MA, the concentration of fungi is higher in samples derived from organic farms (Table 2).

\section{Classification of biosafety (BSL)}

Shown in Table 3, isolates of fungi described due to the risk to people doing various types of work in agriculture.

This was done using the classification established by the European Confederation of Medical Mycology in 1996. The Classification of Biosafety Level (BSL) is the scale of potentially pathogenic fungi for humans and animals, and distinguishes three hazard classes represented by different species of fungi. The class BSL-1 is classified as saprophytes or plant pathogens causing superficial, non-invasive or mild threat. The class BSL-2 species is characterized by a relatively strong ability to survive in vertebrate tissues in patients with severely impaired immunity and can cause deep, opportunistic infection. The class of BSL-3 pathogens is potentially capable of inducing severe deep fungal infections in apparently healthy individuals [12].

Most frequently occurring fungi in settled dust collected during combine threshing mostly belong to the 
Table 1. Fungi identified in dust samples from organic and conventional crops, isolated on Malt Agar (MA) and Potato Dextrose Agar (PDA)

\begin{tabular}{|c|c|c|c|c|}
\hline \multirow{2}{*}{ Fungi } & \multicolumn{2}{|c|}{ Organic farming [\%] } & \multicolumn{2}{|c|}{ Conventional farming [\%] } \\
\hline & PDA & MA & PDA & MA \\
\hline Acremonium charticola & 1.3 & 1.2 & 0.0 & 0.0 \\
\hline Acremonium strictum & 0.0 & 0.5 & 3.4 & 2.1 \\
\hline Alternaria alternata & 16.1 & 24.5 & 12.6 & 18.2 \\
\hline Alternaria sp. & 0.0 & 0.0 & 3.2 & 0.0 \\
\hline Aspergillus candidus & 0.0 & 0.0 & 1.0 & 4.1 \\
\hline Aspergillus glaucus & 0.0 & 0.0 & 1.2 & 1.0 \\
\hline Aspergillus versicolor & 1.5 & 1.6 & 6.1 & 9.4 \\
\hline Aureobasidium pullulans & 15.3 & 2.0 & 6.1 & 3.3 \\
\hline Aureobasidium sp. & 0.0 & 0.7 & 0.0 & 3.0 \\
\hline Blastomyces dermatitidis & 0.0 & 0.9 & 0.0 & 0.0 \\
\hline Chaetomium atrobrunneum & 0.0 & 0.0 & 0.0 & 0.3 \\
\hline Chaetomium sp. & 0.0 & 0.0 & 0.0 & 0.2 \\
\hline Cladosporium herbarum & 0.0 & 5.3 & 3.3 & 0.0 \\
\hline Cladosporium macrocarpum & 11.3 & 9.8 & 11.2 & 10.1 \\
\hline Cladosporium sphaerospermum & 9.1 & 6.4 & 5.0 & 4.0 \\
\hline Fusarium cerealis & 0.9 & 0.0 & 0.0 & 0.0 \\
\hline Fusarium oxysporum & 0.0 & 3.3 & 0.0 & 0.0 \\
\hline Fusarium poae & 12.2 & 10.0 & 10.5 & 10.0 \\
\hline Fusarium solani & 0.0 & 0.0 & 0.0 & 0.5 \\
\hline Fusarium sp. & 0.7 & 0.6 & 2.4 & 0.0 \\
\hline Fusarium sporotrichioides & 0.4 & 0.0 & 2.1 & 0.9 \\
\hline Fusarium tricinctum & 9.2 & 6.9 & 12.5 & 7.3 \\
\hline Gonatobotrys sp. & 1.0 & 0.9 & 0.7 & 2.3 \\
\hline Madurella grisea & 0.0 & 0.0 & 0.0 & 0.4 \\
\hline Microsporum sp. & 0.4 & 0.7 & 0.0 & 0.0 \\
\hline Mucor racemosus & 1.1 & 3.1 & 1.5 & 1.9 \\
\hline Mycelia sterilia & 12.7 & 11.9 & 8.4 & 9.9 \\
\hline Paecilomyces variotii & 0.0 & 0.6 & 0.0 & 0.0 \\
\hline Penicillium chrysogenum & 0.5 & 1.2 & 0.0 & 0.4 \\
\hline Penicillium citrinum & 2.1 & 2.1 & 0.4 & 0.5 \\
\hline Penicillium diversum & 0.0 & 0.1 & 0.0 & 0.0 \\
\hline Penicillium expansum & 2.0 & 2.9 & 4.1 & 3.4 \\
\hline Penicillium gerundense & 0.0 & 0.0 & 2.5 & 3.5 \\
\hline Phialophora sp. & 0.0 & 0.0 & 0.0 & 0.3 \\
\hline Rhizopus oryzae & 0.0 & 0.2 & 0.4 & 0.0 \\
\hline Scopulariopsis brevicaulis & 0.0 & 0.0 & 0.0 & 0.8 \\
\hline Trichoderma harzianum & 0.0 & 0.0 & 0.6 & 0.8 \\
\hline Trichophyton sp. & 0.5 & 0.0 & 1.0 & 0.2 \\
\hline Ulocladium chartarum & 0.0 & 0.0 & 0.0 & 1.2 \\
\hline Ulocladium sp. & 1.6 & 1.1 & 0.0 & 0.0 \\
\hline Yeast-like fungi & 0.3 & 1.1 & 0.0 & 0.0 \\
\hline Total & 100 & 100 & 100 & 100 \\
\hline
\end{tabular}


Table 2. Concentration of fungi in samples of settled rye dust during combine threshing

\begin{tabular}{ccccc}
\hline \multirow{2}{*}{ Sample no. } & \multicolumn{2}{c}{ Organic farming $\left[\times 10^{3}\right.$ CFU/g] } & \multicolumn{2}{c}{ Conventional farming [CFU/g] } \\
\cline { 2 - 5 } & PDA & MA & PDA & 1105 \\
\hline 1 & 1455 & 635 & 1300 & 1330 \\
\hline 2 & 965 & 5725 & 1495 & 1705 \\
\hline 3 & 1835 & 5400 & 11320 & 2700 \\
\hline 4 & 7170 & 1450 & 2380 & 3135 \\
\hline 5 & 1230 & 1910 & 3760 & 2035 \\
\hline 6 & 5270 & 1300 & 2480 & 1420 \\
\hline 7 & 6830 & 6060 & 13445 & 2390 \\
\hline 9 & 5530 & 1110 & 1870 & 1985 \\
\hline 10 & 2100 & 785 & 2690 & 5305 \\
\hline Mean & 2965 & 2595 & 2410 & 2311 \\
\hline
\end{tabular}

BSL-1 class causing a non-invasive or mild danger. Some fungal isolates have not yet been included in the classification of BSL, and several of them are in BSL-2 class that is particularly dangerous for people with immune deficiency.

\section{Activity of extracellular hydrolytic enzymes API ZYM test (bioMérieux)}

Isolated fungi from tested samples of dust were initially used to test with API ZYM (bioMérieux), which enables the assessment of the activity of 19 extracellular hydrolytic enzymes. It is generally believed that the extracellular hydrolytic enzymes secreted by both dermatophytes, yeasts and fungi play an important role in the pathogenesis of infection. These enzymes catalyze reactions of hydrolysis of $\mathrm{C}-\mathrm{O}, \mathrm{C}-\mathrm{N}$, and $\mathrm{C}-\mathrm{C}$ bonds, making it easier for the fungus to invade the tissues, on the other hand they can stimulate the immune inflammation limiting the infection [13].

The greatest number of active hydrolytic enzymes among 9 selected isolates grown on Sabouraud Dextrose Broth (Becton, Dickinson and Company) showed species of Aspergillus versicolor ( $\beta$-glucosidase, alkaline phosphatase) and Fusarium oxysporum ( $\beta$-glucosidase, $\mathrm{N}$-acetyl- $\beta$-glucosaminidase). The smallest number of active hydrolytic enzymes in these isolates was shown by the following species: Cladosporium herbarum, Fusarium cerealis and Penicillium diverse. The highest activity among the tested isolates was shown by the enzymes: $\beta$-glucosidase and $\mathrm{N}$-acetyl- $\beta$-glucosaminidase.

In the studies, of the same isolates on Czapek-Dox Broth (Becton, Dickinson and Company), the highest number of active enzymes showed hydrolytic species of Aspergillus versicolor ( $\alpha$-galactosidase, acid phosphatase, alkaline phosphatase), and Aspergillus candidus ( $\alpha$-galactosidase, $N$-acetyl- $\beta$-glucosaminidase, acid phosphatase, $\beta$-glucosidase), and the least amount of active hydrolytic enzymes in this medium had species of Penicillium expansum and Fusarium oxysporum. The highest activity among the isolates tested in this medium was shown by the same enzymes as in the medium Sabouraud Dextrose Broth i.e. $\beta$-glucosidase and $\mathrm{N}$-acetyl- $\beta$-glucosaminidase. The results of the API ZYM test are presented in Table 4.

\section{Discussion}

Fungal species belonging to different taxonomic groups are important from the point of view of allergology [14]. Most are found in the common genera Cladosporium spp., Alternaria spp., Aspergillus spp., Penicillium spp., and Mucor spp. Due to the structure of their spores (low molecular weight), as compared with the pollen, they are easier lifted in the air and penetrate deeper into the respiratory tract of the human [15]. Then there are the fungi of the genera Botrytis spp., Fusarium spp., Pullularia spp., Curvularia spp., Phoma spp. and Rhizopus spp., which are among the most common allergens causing inhaled allergy [16].

The isolated fungi include species Alternaria alternata. Its spores, and not mycelium, tend to be the cause of allergy. Spores often float in the air, get into the nose and lungs and can cause the symptoms of hay fever and asthma [17].

Another frequently occurring fungi in the tested samples were Fusarium spp., which are cosmopolitan species. The best conditions for the development of Fusarium spp. occur in zones of tropical and temperate climate, although it is also isolated from the desert, alpine, arctic and other extreme environments. Fusarium spp. are common in soil, as saprotrophs. It can also grow on plant debris and various other organic substrates. Some fungi of the genus Fusarium are facultative parasites, which in favorable conditions can cause diseases of plants (in underground and overground parts) [18]. Mushrooms of the genus Fusarium are considered one 
Table 3. Biosafety level (BSL) of fungi isolated from rye dust $[9,12,28,29]$

\begin{tabular}{|c|c|}
\hline Fungi isolated from rye dust & Biosafety level \\
\hline Acremonium charticola & ND \\
\hline Acremonium sp. & ND \\
\hline Acremonium strictum & I \\
\hline Alternaria alternata & I \\
\hline Alternaria sp. & I \\
\hline Aspergillus candidus & I \\
\hline Aspergillus glaucus & I \\
\hline Aspergillus versicolor & I \\
\hline Aureobasidium pullulans & । \\
\hline Aureobasidium sp. & ND \\
\hline Blastomyces dermatitidis & II \\
\hline Chaetomium atrobrunneum & I \\
\hline Chaetomium sp. & I \\
\hline Cladosporium herbarum & I \\
\hline Cladosporium macrocarpum & ND \\
\hline Cladosporium sphaerospermum & I \\
\hline Fusarium cerealis & ND \\
\hline Fusarium oxysporum & II \\
\hline Fusarium poae & ND \\
\hline Fusarium solani & II \\
\hline Fusarium sp. & ND \\
\hline Fusarium sporotrichioides & ND \\
\hline Fusarium tricinctum & ND \\
\hline Gonatobotrys sp. & ND \\
\hline Mycelia sterilia & ND \\
\hline Yeast-like fungi & ND \\
\hline Madurella grisea & $\|$ \\
\hline Microsporum sp. & ND \\
\hline Mucor racemosus & I \\
\hline Paecilomyces variotii & II \\
\hline Penicillium chrysogenum & I \\
\hline Penicillium citrinum & I \\
\hline Penicillium diversum & ND \\
\hline Penicillium expansum & I \\
\hline Penicillium gerundense & ND \\
\hline Phialophora sp. & ND \\
\hline Rhizopus oryzae & II \\
\hline Scopulariopsis brevicaulis & I \\
\hline Trichoderma harzianum & I \\
\hline Trichophyton sp. & ND \\
\hline Ulocladium chartarum & I \\
\hline Ulocladium sp. & ND \\
\hline
\end{tabular}

of the deadliest pathogens of cereals, potatoes, vegetables, ornamental and forest plants causing significant economic losses [19].

In the past 20 years, the interest in fungi of the genus Fusarium spp. increased due to their ability to produce mycotoxins harmful to humans and animals [20]. Contamination of agricultural products with Fusarium mycotoxin is now a worldwide problem [21, 22]. Mycotoxins have the ability to penetrate through the digestive tract, respiratory system and skin. Mycotoxins in high concentrations can damage internal organs leading to severe clinical disease. At low concentration, which is often reported, these compounds can accumulate in human and animal tissues, and cause a variety of chronic diseases, including liver and kidney cancer. These chemicals can get into the eggs, meat and milk of animals fed contaminated feed and become indirectly a threat to human health [23].

Years of research conducted at the Institute of Rural Health have shown that exposure to organic dust can lead to many respiratory syndromes, such as allergic diseases (extrinsic allergic alveolitis - EAA - alveolitis allergica, bronchial asthma, allergic rhinitis, allergic conjunctivitis, allergic dermatitis - hives or airborne eczema), immunotoxic diseases (organic dust toxic syndrome - ODTS, byssinosis, "chronic fatigue syndrome" - "sick building syndrome"), nonspecific diseases, chronic bronchitis [24-26].

In 1932, Campbell described the clinical symptoms of EAA (farmer's lung disease) which affected farmers working with moldy hay [3]. This disease includes a number of diseases with a very similar clinical picture, but caused by different etiological factors. Due to the allergen and the nature of the exposure, it is called farmer's lung, lung threshing, malt worker's lung (brewers), mushroom worker's lung, bagassosis, cheesemaker's disease, bird breeder's lung, maple bark disease, woodworker's disease, suberosis, detergent worker's disease [24].

Another disease that occurs when organic dust is inhaled is the ODTS. Earlier this syndrome was described as mycotoxicosis (pulmonary), atypical farmer's lung, EAA without precipitins, silo unloader syndrome, toxic fever or inhalation fever. The ODTS is defined as a process covering both the airways and alveoli. Characterized by the formation of acute symptoms as the flu-like syndrome with no radiological signs of EAA after exposure to high concentrations of organic dust. The potential etiologic agents in this case are the bacteria and their products (endotoxin), fungi or their spores, mycotoxins, glucans, or other yet unidentified substances. To cause disease a single exposure is sufficient in contrast to the EAA where prior sensitization is necessary. Most cases of ODTS have been found in workers engaged in pig farming and in workers exposed to grain dust [3, 24].

In the etiology of chronic bronchitis (CB), the organic powder is one of the risk factors. The main importance 
Table 4. Activity of enzymes secreted by isolated fungi on media Czapek-Dox Broth (Czapek) and Sabouraud Dextrose Broth (Sabouraud)

\begin{tabular}{|c|c|c|c|c|c|c|c|c|c|c|c|c|c|c|c|c|c|c|c|c|}
\hline \multirow[t]{2}{*}{ Isolates } & \multirow[t]{2}{*}{ Medium } & \multicolumn{19}{|c|}{ Activity of enzymes ${ }^{\star, \star *}$} \\
\hline & & 1 & 2 & 3 & 4 & 5 & 6 & 7 & 8 & 9 & 10 & 11 & 12 & 13 & 14 & 15 & 16 & 17 & 18 & 19 \\
\hline \multirow{2}{*}{$\begin{array}{l}\text { Aspergillus } \\
\text { candidus }\end{array}$} & Czapek & 3 & 2 & 1 & - & 1 & 2 & 1 & - & - & 4 & 2 & 5 & 2 & - & - & 4 & 5 & - & - \\
\hline & Sabouraud & 3 & - & 1 & - & - & 1 & - & - & - & 1 & 2 & 3 & 2 & - & - & 4 & 1 & 2 & - \\
\hline \multirow{2}{*}{$\begin{array}{l}\text { Alternaria } \\
\text { alternata }\end{array}$} & Czapek & - & 2 & 3 & - & 2 & 1 & - & 4 & - & 1 & 1 & 2 & - & - & 1 & 5 & 5 & - & - \\
\hline & Sabouraud & - & - & - & - & 1 & 1 & - & 1 & - & - & 1 & 2 & - & - & 1 & 5 & 2 & - & - \\
\hline \multirow{2}{*}{$\begin{array}{l}\text { Penicillium } \\
\text { chrysoge- } \\
\text { num }\end{array}$} & Czapek & - & 1 & 1 & - & 5 & 2 & - & - & - & - & 1 & - & 2 & - & 3 & 4 & 4 & - & 2 \\
\hline & Sabouraud & - & - & - & - & - & - & - & - & - & - & 2 & - & 2 & - & 1 & 3 & 1 & - & - \\
\hline \multirow{2}{*}{$\begin{array}{l}\text { Aspergillus } \\
\text { versicolor }\end{array}$} & Czapek & 4 & 1 & 2 & - & 1 & 1 & - & - & - & 4 & 2 & 5 & 3 & - & - & 3 & 3 & - & - \\
\hline & Sabouraud & 4 & 2 & 2 & - & 1 & 2 & 1 & - & - & 1 & 2 & 1 & 1 & - & 1 & 5 & 2 & 2 & - \\
\hline \multirow{2}{*}{$\begin{array}{c}\text { Penicillium } \\
\text { diverse }\end{array}$} & Czapek & 4 & - & - & - & 1 & 4 & - & - & - & 3 & 2 & - & - & - & - & 5 & 4 & - & - \\
\hline & Sabouraud & 2 & - & - & - & 3 & - & - & - & - & 1 & 2 & - & - & - & - & 3 & 3 & - & - \\
\hline \multirow{2}{*}{$\begin{array}{l}\text { Penicillium } \\
\text { expansum }\end{array}$} & Czapek & - & - & 1 & - & - & - & - & - & - & - & - & - & - & 2 & - & 3 & - & 1 & - \\
\hline & Sabouraud & 1 & - & 1 & - & 1 & - & - & - & - & - & 1 & - & 2 & - & - & 3 & 1 & - & - \\
\hline \multirow{2}{*}{$\begin{array}{l}\text { Clado- } \\
\text { sporium } \\
\text { herbarum }\end{array}$} & Czapek & 2 & 2 & 1 & - & - & - & - & - & - & 1 & 1 & 3 & - & - & - & 4 & 4 & - & - \\
\hline & Sabouraud & - & 1 & - & - & - & - & - & - & - & - & - & 1 & - & - & - & 1 & 3 & - & - \\
\hline \multirow{2}{*}{$\begin{array}{l}\text { Fusarium } \\
\text { oxysporum }\end{array}$} & Czapek & - & 1 & 2 & 1 & 3 & - & - & 1 & - & - & - & - & 1 & - & - & 2 & 2 & - & - \\
\hline & Sabouraud & 3 & 1 & 1 & 1 & 1 & - & - & 1 & - & 3 & 2 & - & - & - & - & 5 & 5 & - & - \\
\hline \multirow{2}{*}{$\begin{array}{l}\text { Fusarium } \\
\text { tricinctum }\end{array}$} & Czapek & 2 & 2 & 2 & - & 1 & - & - & 1 & - & 4 & - & - & - & - & - & 4 & - & - & - \\
\hline & Sabouraud & 3 & - & 1 & - & 1 & - & - & - & - & 2 & 4 & 1 & - & - & - & 3 & 3 & - & - \\
\hline \multirow{2}{*}{$\begin{array}{c}\text { Fusarium } \\
\text { cerealis }\end{array}$} & Czapek & 1 & 2 & 2 & - & 1 & - & - & 4 & - & 1 & 1 & - & 1 & - & - & 5 & - & - & - \\
\hline & Sabouraud & 2 & 1 & - & - & - & - & - & - & - & 1 & 2 & - & - & - & - & 3 & 4 & - & - \\
\hline
\end{tabular}


is given to compulsive smoking and genetic factors, but exposure to organic dust may increase the incidence of the disease [24].

Asthma is a chronic inflammatory disease of the airways. Bronchial asthma as a result of exposure to organic dust can occur in different environments (agriculture, food processing, contact with wood dust). The main etiological factors of asthma are dust antigens in plants: cereal, flour, wood, dust from flax and hemp, cotton, coffee, tea, tobacco, hops and dust of animal origin: fur, feathers, excrement, skin and other protein substances. Because of its insidious onset, asthma is often mistakenly diagnosed as chronic bronchitis and is therefore not treated or treated inappropriately $[23,27]$.

\section{Conclusions}

All the obtained results show a potential risk of people involved in agricultural work on the organic components of grain dust, which contain toxinogenic and allergenic molds, thus indicate a substantial degree of occupational exposure.

Health statistics show that most of occupational diseases reported in Polish farmers is caused by pathogens present in organic dusts. In Poland, lung diseases are more common in farmers than in the rest of the population, just as in other countries. Therefore, the problem is serious, of social background and appropriate preventive measures need to be taken.

\section{Acknowledgments}

The project was funded by the National Science Centre on the basis of decision DEC-2011/01/B/NZ7/04300.

\section{References}

1. Runowski H. Rolnictwo ekologiczne - rozwój czy regres [Polish]? Roczniki Nauk Rolniczych. Seria G 2009; 96: 182-93.

2. Rozporządzenie MRiRW z dnia 14 maja 2002 r. w sprawie szczegółowych warunków wytwarzania produktów rolnic twa ekologicznego [Dz. U. 2002, Nr 77, poz. 699] [Polish].

3. Pałczyński C, Kieć-Świerczyńska M. Alergologia i toksykologia kliniczna w środowisku wiejskim [Polish]. Wydawnictwo Biblioteka, Łódź 2000; 28-29, 41, 67, 73-74.

4. Jenerowicz D, Silny W, Dańczak-Pazdrowska A, et al. Environmental factors and allergic diseases. Ann Agric Environ Med 2012; 19: 475-81.

5. Ramirez C. Manual and atlas of the Penicillia. Elsevier Biomedical Press, Amsterdam 1982.

6. Baran E. Zarys mikologii lekarskiej [Polish]. Volumed, Wrocław 1998.

7. Larone DH. Medically important fungi. A guide to identification. ASM Press 2011.

8 Kwaśna H, Chełkowski J, Zajkowski P. Grzyby [Polish]. Tom XXII, Instytut Botaniki PAN, Kraków 1991.

9. Krzyściak P, Skóra M, Macura AB. Atlas grzybów chorobotwórczych człowieka [Polish]. MedPharm Polska 2011.
10. Samson RA, Hoekstra ES, Frisvad JC, Filtenborg O. Introduction to food - and airborne fungi. Centraalbureau voor Schimmelcultures, Utrecht, The Netherlands 2002.

11. Żukiewicz-Sobczak W, Cholewa G, Krasowska E, et al. Pathogenic fungi in the work environment of organic and conventional farmers. Postep Derm Alergol 2012; 29: 256-62.

12. Informacja Zarządu Sekcji Mikologicznej PTD, Katedra i Klinika Dermatologii i Wenerologii AM we Wrocławiu. Mikol Lek 1998; 5: 193-6.

13. Nowicki R, Korting HC. Różnice w aktywności hydrolitycznej dermatofitów [Polish]. Mikol Lek 1995; 4: 209-13.

14. Zawisza E. Zapalenie alergiczne i niealergiczne wywołane kontaktem z grzybami [Polish]. Alergia 2007; 4: 16-20.

15. Krajewska-Kułak E. Zarys mikologii dla pielęgniarek [Polish]. Czelej, Lublin 2005; 103-4.

16. Lipiec A. Grzyby w etiologii chorób alergicznych [Polish]. Alergol Współcz 2002; 1: 10-4.

17. Nolard N. Mold allergy: 25 years of indoor and outdoor studies in Belgium. Allergy Immunol 2001; 33: 101-2.

18. Nelson PE. Fusarium. APS Press, ST. Paul, Minnesota 2002; 1-392.

19. Champeil A, Doré T, Fourbet JF. Fusarium head blight: epidemiological origin of the effects of cultural practices on head blight attacks and the production of mycotoxins by Fusarium in wheat grains. Plant Sci 2004; 166: 1389-415.

20. Gang G, Miedaner U, Schuhmacher U, et al. Deoxynivalenol and nivalenol production by Fusarium culmorum isolates differing in aggressiveness towards winter rye. Phytopathology 1998; 88: 879-84.

21. Bottalico A, Perrone G. Toxigenic Fusarium species and micotoxins associated with head blight in small-grain cereals in Europe. Eur J Plant Pathol 2002; 108: 611-24.

22. Kelishadi R, Poursafa P. Air pollution and non-respiratory health hazards for children. Arch Med Sci 2010; 6: 483-95.

23. Bata $\ddot{A}$, Lasztity R. Detoxification of mycotoxin-contaminated ford and feed by microorganisms. Trends Food Science Technol 1999; 10: 223-8.

24. Dutkiewicz J, Skórska C, Mackiewicz B, Cholewa G. Zapobieganie chorobom wywołanym przez pyły organiczne w rolnictwie i przemyśle rolnym [Polish]. Instytut Medycyny Wsi, Lublin 2000; 5: 24-32.

25. Żukiewicz-Sobczak W. The role of fungi in allergic diseases. Postep Derm Alergol 2013; 30: 42-5.

26. Klimańska M, Żmudzińska M, Jenerowicz D, Czarnecka-Operacz $M$. The importance of exposure to contact allergens in patients with allergic contact dermatitis. Postep Derm Alergol 2011; 28: 203-11.

27. Jahnz-Rozyk K, Targowski T, Owczarek W, et al. Effects of allergic diseases, concomitant with allergic rhinitis, on the clinical efficacy and costs of allergen-specific immunotherapy in Poland. Postep Derm Alergol 2011; 28: 378-81.

28. de Hoog GS. Risk assessment of fungi reported from humans and animals. Mycoses 1996; 39: 407-17.

29. de Hoog GS, Zalar P, van den Ende BG, Gunde-Cimerman N. Relations of halotolerance to human-pathogenicity in the fungal tree of life: an overview of ecology and evolution under stress. Adaptation to Life at High Salt Concentrations in Archaea, Bacteria, and Eukarya 2005; 9: 371-95. 